\title{
Konseling Rational Emotif Behaviour Theraphy (Rebt)-Islami \\ (Sebuah Pendekatan Integrasi Keilmuan)
}

\author{
Hasan Bastomi \\ IAIN Kudus, Jawa Tengah, Indonesia \\ tommy.wedung@gmail.com
}

\begin{abstract}
Abstrak
Adanya spesialisasi ilmu adalah sebuah keniscayaan. Namun juga membawa dampak yang negatif, terjadi suatu arogansi, ketika dihadapkan pada problem-problem realitas kemasyarakatan, begitu juga di dalam kajian konseling. Maka Integrasi keilmuan dapat menjadi paradigma pilihan. Oleh karena itu, perlu ditekankan kajian keagamaan, baik hal itu berasal dari perspektif Indigenous Counseling yang cross cultural dan mengungkap variabel budaya lokal maupun Konseling Agama terhadap pembentukan karakter individu. Artikel ini mengintegrasikan pendekatan konseling REBT dengan ajaran Islam. REBT Islami adalah sebuah pendekatan konseling mengakomodasi keyakinan agama klien yang mana keyakinan agama klien dapat memberikan struktur penting kepada skema pengorganisasian kepribadian klien. Maka REBT Islami sangat cocok untuk mengintegrasikan keyakinan agama klien dalam intervensi konseling.
\end{abstract}

Kata Kunci: Konseling REBT, Islami, Integrasi Keilmuan

\begin{abstract}
The existence of specialization of science is a necessity. But it also carries a negative impact, an arrogance occurs when faced with problems of social reality, as well as in counselling studies. So the integration of science can be the choice paradigm. Therefore, it should be emphasized religious studies, whether it comes from the perspective of cross cultural Indigenous Counseling and reveals local cultural variables and Religious Counseling on the formation of individual characters. This article integrates REBT counseling approach with the Islamic teachings. Islamic REBT is a
\end{abstract}




\section{Konseling Rational Emotif Behaviour Theraphy (Rebt)-Islami ...}

counseling approach accommodating the client's religious beliefs in which the client's religious beliefs can provide an important structure to the scheme of organizing client's personality. So Islamic REBT is suitable for integrating the client's religious beliefs in counseling interventions.

\section{Keywords: REBT Counseling, Islamic, Integration of Science}

\section{A. Pendahuluan}

Adanya spesialisasi ilmu adalah sebuah keniscayaan, karena keterbatasan manusia untuk mengetahui semuanya, walaupun objeknya adalah sama yaitu alam. Akan tetapi efek dari bentuk spesialisasi tersebut ternyata juga membawa dampak yang negatif, terjadi suatu arogansi, ketika dihadapkan pada problem-problem realitas kemasyarakatan. Mulanya hanya dalam tataran berpikirteoretis keilmuan yang bersifat abstrak, tapi pada ujungnya juga berdampak pada tataran bentuk konflik praktis-sosiologis. Contoh, seorang ahli ilmu fiqih akan merasa kebingungan jika dihadapkan pada konteks sosiologis, ahli ekonomi akan kesulitan memahami logika zakat, sehingga tidak jarang sampai terjadi suatu bentuk pengkafiran dalam sebuah pemikiran (takfír al-fikr) (Faiz, 2007 viii).

Berangkat dari fakta bahwa dunia Islam dewasa ini cenderung membuat dikotomi antara ilmu agama dengan ilmu umum, maka Amin Abdullah, merasa perlu merekonstruksi fakta ini dan membuat sebuah restorasi paradigma keilmuan. Pemahaman dikotomi yang rigid ini membuat polarisasi yang dikotomis antara ilmu sharî́ah dan ilmu ghayr al-sharî‘ah. Pemahaman ilmu ghayr alsharî'ah-yang jumlahnya jauh lebih banyak-tidak penting untuk dipelajari, yang penting adalah ilmu sharî‘ah, ilmu yang menuntun orang untuk memasuki surga dan menghindari neraka, merupakan hal yang bisa menghambat kemajuan kajian keislaman (Abdullah, 1999: 3).

Dikotomi ini sangat membekas di hati kaum Muslim. Terbukti sebagian besar orang sekarang masih terkesan bahwa ilmu keislaman adalah satu hal dan ilmu non-keislaman adalah hal lain. Dikotomi keilmuan seperti ini jelas akan merugikan dunia Islam itu sendiri. Sebab ilmu-ilmu non-keagamaan dianggap tidak penting, 
sehingga tidak perlu dipelajari. Inilah salah satu faktor terbesar mundurnya keilmuan Islam. Bandingkan dengan abad pertengahan ketika muncul tokoh-tokoh yang tidak melihat dikotomi itu semisal Ya,qûb Ishâq al-Kindî (801-873 M) (Nasr, Suharsono, \& MZ, 1996: 33-34), Abû Nâsir Muhammad al-Farakh al-Fârâbî (257-339H/ 870950M)4 dan Abû Alî al-Husayn Abdullah Sînâ (370-428H/980$1037 \mathrm{M}) 5$ yang di samping menguasai keilmuan Islam tradisional juga disegani sebagai pakar ilmu non-keagamaan. Pada saat itu Islam mampu menunjukkan perannya sebagai kontributor ilmu ketika Barat sendiri mengalami kemunduran ilmiah. Tapi hari ini, akibat dikotomi yang telah diciptakan dan diwariskan sejak ratusan tahun itu, dunia Islam terpuruk dalam ketertinggalan. Barat sekarang tampil di puncak kemajuan peradaban ilmu.

Fenomena tersebut jelas membawa kegelisahan bagi pemikir-pemikir Muslim modern. Integrasi-interkoneksi keilmuan dapat menjadi paradigma pilihan. Paradigma integrasi-interkoneksi mengandaikan terbukanya dialog di antara ilmu-ilmu. Peluang dikotomi ditutup rapat. Tiga peradaban dipertemukan di dalamnya, yakni hadârah al-nass (budaya teks), hadârah al-'ilm (budaya ilmu), dan hadârah al-falsafah (budaya filsafat). Pendekatan yang memadukan wahyu Tuhan dengan temuan pikiran manusia ini tidak akan berakibat mengecilkan peran Tuhan (sekularisasi) atau mengucilkan manusia sehingga teralienasi dari dirinya sendiri, masyarakat, dan lingkungannya. Namun konsep ini sekaligus akan dapat menyelesaikan konflik antara sekularisme ekstrem dan fundamentalisme negatif.

Begitu juga didalam kajian konseling, Abraham Maslow membagi empat mazhab besar disiplin Psikologi konseling, yaitu Psikoanalisa, Behaviorisme, Humanisme, dan Psikologi Transpersonal. Pembagian empat mazhab itu juga masih memiliki kelemahan, yaitu tidak memasukkan peran agama secara signifikan ke dalam disiplin konseling. Apalagi jika memperhatikan pendapat ilmuwan positivistik yang cenderung memisahkan agama dan ilmu pengetahuan. Padahal, kepribadian individu yang terbentuk dari unsur bio-psiko-spiritual sangat dipengaruhi oleh agama. Jadi tak mengherankan jika ahli Konseling Islam mengatakan bahwa Konseling Islam akan bergerak menjadi mazhab kelima dari disiplin 


\section{Konseling Rational Emotif Behaviour Theraphy (Rebt)-Islami ...}

psikologi dengan cara mengembalikan paradigma ilmuwan kepada orientasi dunia dan akhirat.

Oleh karena itu, perlu ditekankan kajian keagamaan, baik hal itu berasal dari perspektif Indigenous Counseling yang cross cultural dan mengungkap variabel budaya lokal maupun Konseling Agama itu sendiri terhadap pembentukan karakter individu. Upaya dalam integrasi keilmuan bidang konseling dapat dilakukan dengan integrasi pendekatan konseling dengan kajian Islam. Dalam kajian ini yang dilakukan penulis yaitu dengan mengintegrasikan pendekatan Rasional Emotif Behavior Therapy (REBT) dengan Islam. Oleh karena itu, yang menjadi problem adalah bagaimana mengintegrasikan pendekatan REBT dengan ajaran Islam sehingga harapannya pendektan REBT dapat sesuai dengan konteks masyarakat Indonesia yang beragama (Islam).

\section{B. Pembahasan}

\section{Pendekatan Rasional Emotif Behaviour Theraphy (REBT)}

Menurut Gerald Corey terapi rasional emotif behaviour theraphy adalah pemecahan masalah yang fokus pada aspek berpikir, menilai, memutuskan, direktif tanpa lebih banyak berurusan dengan dimensi-dimensi pikiran ketimbang dengan dimensi-dimensi perasaan (Corey, 2012: 189). Rasional Emotif Behavior Therapy (REBT) pada masanya berbeda dari terapi utama lainnya, terutama dalam hal pentingnya membahas menempatkan dan mengadaptasi bagaimana klien berpikir (Ackerman, 2017).

Albert Ellis menyebutnya "Rasional Terapi". Ellis melakukannya karena ingin menekankan masalah emosi didasarkan pada pemikiran irasional dan bahwa jika kita mengatasi masalah ini secara efektif, kita perlu mengubah pemikiran tersebut pada pemikiran rasionalnya (Ellis, 1958: 35-49). REBT diciptakan oleh Albert Ellis pada tahun 1955, REBT berpendapat bahwa dalam menghadapi kesulitan (seperti kehilangan pekerjaan), bukan situasi itu sendiri yang menyebabkan disfungsional emosi seperti depresi, tetapi keyakinan tentang situasi (Ellis \& Dryden, 1997). Secara khusus, REBT menunjukkan bahwa emosi disfungsional yang tidak sehat (seperti emosi kecemasan), dan perilaku maladaptif terkait (misalnya, penarikan diri), berasal dari keyakinan irasional. Sebaliknya, emosi fungsional yang sehat (missal; seperti 
kekhawatiran), dan perilaku adaptasi terkait (misalnya, ketegasan), berasal dari keyakinan rasional (Ellis \& Dryden, 1997). Dalam REBT ada empat jenis keyakinan irasional, satu primer (tuntutan) dan tiga sekunder (ketakutan, toleransi rendah, frustrasi, depresiasi diri); kepercayaan sekunder berasal dari keyakinan utama. Secara paralel, ada juga empat jenis keyakinan rasional, satu primer (preferensi) dan tiga toleransi sekunder (ketakutan, frustrasi tinggi, penerimaan diri); sekali lagi keyakinan sekunder berasal dari keyakinan primer (Dryden, 2012: 56).

Selain itu menurut W.S. Winkel REBT pendekatan konseling yang menekankan kebersamaan dan interaksi antara berpikir dengan akal sehat, berperasaan dan berperilaku, serta menekankan pada perubahan yang mendalam dalam cara berpikir dan berperasaan yang berakibat pada perubahan perasaan dan perilaku (Winkel, 2005: 364).

Dari beberapa definisi diatas dapat disimpulkan, bahwa terapi rasional emotif merupakan terapi yang berusaha menghilangkan cara berpikir klien yang tidak logis, tidak rasional dan menggantinya dengan sesuatu yang logis dan rasional dengan cara mengonfrontasikan klien dengan keyakinankeyakinan irasionalnya serta menyerang, menentang, mempertanyakan, dan membahas keyakina-keyakinan yang irasional.

Konsep-konsep dasar terapi rasional emotif ini mengikuti pola yang didasarkan pada teori A-B-C, yaitu: A = Activating Experence (pengalaman aktif) Ialah suatu keadaan, fakta peristiwa, atau tingkah laku yang dialami individu. B = Belief System (Cara individu memandang suatu hal). Pandangan dan penghayatan individu terhadap A. C = Emotional Consequence (akibat emosional). Akibat emosional atau reaksi individu positif atau negative. Menurut pandangan Ellis, A (pengalaman aktif) tidak langsung menyebabkan timbulnya C (akibat emosional), namun bergantung pada B (belief system). Hubungan dan teori A-B-C yang didasari tentang teori rasional emotif dari Ellis dapat digambarkan sebagai berikut:

Teori A-B-C tersebut, sasaran utama yang harus diubah adalah aspek B (Belief Sistem) yaitu bagaimana caranya seseorang itu memandang atau menghayati sesuatu yang irasional, sedangkan konselor harus berperan sebagai pendidik, pengarah, 


\section{Konseling Rational Emotif Behaviour Theraphy (Rebt)-Islami ...}

mempengaruhi, sehingga dapat mengubah pola pikir klien yang irasional atau keliru menjadi pola pikir yang rasional. Dari uraian diatas, disimpulkan bahwa permasalahan yang menimpa seseorang merupakan kesalahan dari orang itu sendiri yang berupa prasangka yang irasionals terhadap pandangan penghayatan individu terhadap pengalaman aktif.

Ciri-ciri Rasional Emotif Behavior Therapy (REBT) adalah dapat diuraikan sebagai berikut: (1) Dalam menelusuri masalah klien yang dibantunya, konselor berperan lebih aktif dibandingkan klien. Maksudnya adalah bahwasannya peran konselor disini harus bersikap efektif dan memiliki kapasitas untuk memecahkan masalah yang dihadapi klien dan bersungguh-sungguh dalam mengatasi masalah yang dihadapi, artinya konselor harus melibatkan diri dan berusaha menolong kliennya supaya dapat berkembang sesuai dengan keinginan dan disesuaikan dengan potensi yang dimilikinya. (2) Dalam proses hubungan konseling harus tetap diciptakan dan dipelihara hubungan baik dengan klien. Dengan sikap yang ramah dan hangat dari konselor akan mempunyai pengaruh yang penting demi suksesnya proses konseling sehingga dengan terciptanya proses yang akrab dan rasa nyaman ketika berhadapan dengan klien. Tercipta dan terpeliharanya hubungan baik ini dipergunakan oleh konselor untuk membantu klien mengubah cara berfikirnya yang tidak rasional menjadi rasional. (3) Dalam proses hubungan konseling, konselor tidak banyak menelusuri masa lampau klien (Sukardi, 2008: 89).

Tujuan rational emotive behavior therapy (REBT) menurut Ellis, membantu klien untuk memperoleh filsafat hidup yang lebih realistik" yang berarti menunjukkan kepada klien bahwa verbalisasiverbalisasi diri mereka telah dan masih merupakan sumber utama dari gangguan-gangguan emosional yang dialami oleh mereka (Natawidjaya, 2009: 275). Sedangkn Tujuan dari Rational Emotive Behavior Therapya menurut Mohammad Surya sebagai berikut: (1) Memperbaiki dan mengubah segala perilaku dan pola fikir yang irasional dan tidak logis menjadi rasional dan lebih logis agar klien dapat mengembangkan dirinya. (2) Menghilangkan gangguan emosional yang merusak. (3) Untuk membangun Self Interest, Self Direction, Tolerance, Acceptance of Uncertainty, Fleksibel, 
Commitment, Scientific Thinking, Risk Taking, dan Self Acceptance Klien (Surya, 1988). Dengan demikian tujuan rational emotive behaviour therapy adalah menghilangkan gangguan emosional yang dapat merusak diri (seperti benci, rasa bersalah, cemas, dan marah) serta mendidik klien agar mengahadapi kenyataan hidup secara rasional.

\section{Konseling Islami}

Pengertian Bimbingan dan Konseling Islam pada dasarnya adalah sama dengan pengertian Bimbingan penyuluhan, hanya saja Bimbingan dan Penyuluhan Islam pada pelaksanaannya berdasarkan atas nilai-nilai keagamaan, sebagaimana yang dipaparkan oleh H. M. Arifin yang dikutip pada buku karangan Imam Sayuti Farid yang berjudul "Pokok-pokok Bahasan Tentang Penyuluhan Agama" menyatakan bahwa Bimbingan dan penyuluhan agama adalah “ segala kegiatan yang dilakukan oleh seseorang dalam memberikan bantuan kepada orang lain, yang mengalami kesulitan-kesulitan rohaniah dalam lingkungan hidupnya, supaya orang tersebut mampu mengatasinya sendiri karena timbul kesadaran atau penyerahan diri terhadap kekuasaan Tuhan Yang Maha Esa, sehingga timbul pada diri pribadinya suatu cahaya harapan, kebahagiaan hidup pada saat sekarang dan masa depannya (Farid, 2007: 25).

Konseling merupakan salah satu bentuk hubungan yang bersifat membantu. Makna bantuan di sini yaitu sebagai upaya untuk membantu orang lain agar ia mampu tumbuh ke arah yang dipilihnya sendiri, mampu memecahkan masalah yang dihadapinya dan mampu mengatasi krisis-krisis yang dialami dalam kehidupannya (Syamsu \& Juntika, 2005: 10). Dari beberapa batasan tersebut di atas dapat di simpulkan bahwa konseling adalah suatu bimbingan yang diberikan kepada individu (siswa) dengan tatap muka (face to face) melalui wawancara (Mu'awanah \& Hidayah, 2009: 56).

Hakekat bimbingan dan konseling Islami adalah upaya membantu individu belajar mengembangkan fitrah dan atau kembali kepada fitrah-iman dan atau kembali kepada fitrah-iman, dengan cara memperdayakan (empowering) fitrah-fitrah (jasmani, rohani, nafs, dan iman) mempelajari dan melaksanakan tuntutan Allah dan rasul-Nya, agar fitrah yang ada pada individu berkembang dan berfungsi dengan baik dan benar. Pada akhirnya diharapkan agar 


\section{Konseling Rational Emotif Behaviour Theraphy (Rebt)-Islami ...}

individu selamat dan memperoleh kebahagiaan yang sejati di dunia dan akhirat (Sutoyo, 2003: 207).

Dari rumusan di atas tampak, bahwa konseling Islam adalah aktifitas yang bersifat "membantu", dikatakan membantu karena pada hakekatnya individu sendirilah yang perlu hidup sesuai tuntutan Allah (jalan yang lurus) agar mereka selamat. Karena posisi konselor bersifat membantu, maka konsekuensinya individu sendiri yang harus aktif belajar memahami dan sekaligus melaksanakan tuntutan Islam (al-Qur"an dan sunah rasul-Nya). Pada akhirnya diharapkan agar individu selamat dan memperoleh kebahagiaan yang sejati di dunia dan akhirat, bukan sebaliknya kesengsaraan dan kemelaratan di dunia dan akhirat (Sutoyo, 2003: 22).

Implementasi menurut Kamus Besar Bahasa Indonesia adalah pelaksanaan, penerapan (Tim Penyusun, 1988: 327). Implementasi merupakan suatu proses penerapan ide, konsep, kebijakan atau inovasi dalam suatu tindakan praktis sehingga memberikan dampak, baik berupa pengetahuan, ketrampilan, maupun nilai dan sikap (Mulyasa, 2003: 93). Maksud implementasi disini adalah penerapan ide, kebijakan atau inovasi dalam bentuk suatu tindakan mengenai penerapan bimbingan dan konseling Islam dalam kehidupan di sekolah untuk mencegah kenakalan remaja.

Bimbingan konseling Islam merupakan suatu proses hubungan pribadi yang terprogram, antara seorang konselor dengan satu atau lebih klien (konseli) atau remaja, dimana konselor dengan bekal pengetahuan profesional dalam bidang ketrampilan dan pengetahuan psikologis yang dikombinasikan dengan pengetahuan keislaman membantu klien dalam upaya mengatasi masalah serta membantu kesehatan mental, sehingga dari hubungan tersebut klien dapat menanggulangi problematika hidup dengan baik dan benar secara mandiri yang berpandangan pada Al-Qur"an dan AS-sunnah. Nilai bimbingan yang terdapat dalam ajaran al-Qur'an dan hadis dapat digunakan pembimbing untuk membantu si terbimbing dalam menentukan pilihan perubahan tingkah laku positif. Diantaranya dasar-dasar bimbingan dan konseling dalam al-Qur'an dan hadis antara lain: 


\section{Hasan Bastomi}

\section{a. Perintah untuk mengajak kepada kebaikan}

Sebagaimana dalam QS. An-Nahl/16: 125 yang artinya: Serulah (manusia) kepada jalan Tuhan-mu dengan hikmah dan pelajaran yang baik dan bantahlah mereka dengan cara yang baik. Sesungguhnya Tuhanmu Dialah yang lebih mengetahui tentang siapa yang tersesat dari jalan-Nya dan Dialah yang lebih mengetahui orang-orang yang mendapat petunjuk. (QS. An-Nahl/16: 125) (Depag RI, 2010: 417). Ayat tersebut berisi tentang anjuran mengajak kepada kebaikan, dan memberikan pelajaran yang baik. Dari ayat ini dapat dilihat nilai korelasi yang tepat dengan bimbingan dan konseling Islam, di dalam ayat ini terdapat fungsi-fungsi serta tujuan dari bimbingan dan konseling Islam, yang didalamnya terdapat juga fungsi pencegahan dengan cara yang baik, atau membimbing nilai kesalahan dan menuju pada nilai-nilai kebaikan.

\section{b. Perintah untuk nasehat dan menasehati}

Dijelaskan dalam Q.S. al-Asr/103: 1-3 yang artinya: Demi masa. Sesungguhnya manusia itu benar-benar dalam kerugian. Kecuali orang-orang yang beriman dan mengerjakan amal saleh dan nasehat menasehati supaya mentaati kebenaran dan nasehat menasehati supaya menetapi kesabaran. (Q.S. al-Asr/103: 1-3) (Depag RI, 2010: 766). Dari ayat tersebut terdapat nilai-nilai kandungan dari bimbingan dan konseling Islam. Yaitu adanya upaya membantu dalam kebaikan serta kesabaran, dalam hal ini kegiatan yang bersifat membantu, menasehati, mengarahkan, adalah ruang lingkup dari tujuan bimbingan dan konseling Islam.

\section{c. Perintah untuk menjaga diri dan sesama}

Dijelaskan dalam QS. Al-Isra"/17: 82 yang artinya: Hai orangorang yang beriman, peliharalah dirimu dan keluargamu dari api neraka yang bahan bakarnya adalah manusia dan batu; penjaganya malaikat-malaikat yang kasar, keras, dan tidak mendurhakai Allah terhadap apa yang diperintahkan-Nya kepada mereka dan selalu mengerjakan apa yang diperintahkan" (QS. Al-Isra"/17: 82) (Depag RI, 2010: 203). Ayat tersebut berisi tentang perintah untuk menjaga diri sendiri dan keluarga (sesama) dalam hal kebaikan, kandungan ayat ini relevan dengan fungsi-fungsi dari bimbingan dan konseling Islam, karena fungsi pemeliharaan adalah salah satu dari fungsi bimbingan dan konseling Islam. 


\section{Konseling Rational Emotif Behaviour Theraphy (Rebt)-Islami ...}

\section{d. Penguatan Agama Melalui Nasihat dan Bimbingan Konseling Islam}

Sebagaimana dalam hadis yang artinya: Hak seorang muslim pada muslim lainnya ada enam: jika berjumpa hendaklah memberi salam; jika mengundang dalam sebuah acara, maka datangilah undangannya; bila dimintai nasehat, maka nasehatilah ia; jika memuji Allah dalam bersin, maka doakanlah; jika sakit jenguklah ia; dan jika meninggal dunia, maka iringilah kekuburnya. (HR Muslim) (Vandestra \& Muslim, 2017: 1705).

Hadits di atas merupakan salah satu hadits yang mengandung nilai tentang bimbingan dan konseling Islam, yaitu mengenai sikap menolong atau memberi bantuan. Di lihat dari hadits ini menganjurkan bagi seorang pembimbing maupun konselor untuk senantiasa membantu peserta didik dalam mengahadapi masalahnya. Serta menganjurkan untuk melakukan suatu kebaikan, yang berhubungan dengan ajaran Islam.

\section{e. Nilai-Nilai Dasar Bimbingan Konseling Islam}

Dari Abu Hurairah ra berkata: Rasulullah saw bersabda: barang siapa yang dapat menghilangkan kesusahan seorang mukmin di dunia, niscaya Allah akan menghilangkan kesusahannya kelak diakhiratnya; dan barang siapa yang memudahkan orang yang mendapatkan kesulitan, niscaya Allah akan memudahkan kesulitannya di dunia dan di hari kemudian ; dan barang siapa yang merahasiakan keburukan orang Islam, niscaya Allah akan menutup segala keburukannya di dunia dan di akhiratnya; Dan Allah akan selalu menolong hambanya, selama hambanya itu senantiasa memberikan bantuan kepada saudaranya; barang siapa menginjakkan kaki di jalan Allah untuk mencari ilmu, niscaya Allah akan memberikan kemudahan jalan menuju surga. Tidak seorangpun yang berkumpul dalam suatu majlis di berbagai rumah Allah dengan belajar dan mengkaji kitab Allah, kecuali di antara mereka itu akan memperoleh ketenangan, meraih rahmat, memperoleh perlindungan dari para malaikat dan bahkan Allah menyebutkan mereka dengan orang-orang yang berada di sekitarnya. Barang siapa yang menghapuskan segala amalnya, maka mereka tidak disebut sebagai kelompok yang dimaksudkan. (HR Tirmidzi). Hadits tersebut mengandung aspek-aspek dalam pelaksanaan bimbingan dan 
konseling Islam, aspek tersebut antara lain adalah aspek membantu dan juga aspek pengetahuan. Maksudnya dalam memberikan bimbingan dan konseling terhadap peserta didik tidak hanya memperhatikan dari segi bantuan, tetapi juga dilihat dari segi pengetahuan. Salah satu contoh penerapan bimbingan dan konseling Islam, diterapkan dalam bentuk kegiatan-kegiatan sekolah yang mengandung nilai-nilai keislaman, mulai dari kegiatan awal maupun sampai kegiatan akhir harus bisa diarahkan pada penanaman karakter akhlakul karimah, sehingga peserta didik, senantiasa menjadi peserta didik yang tangkas dalam menghadapi dampak pergaulan bebas.

Fungsi pencegahan termasuk dalam bimbingan dan konseling Islam seperti dijelaskan dalam hadis yang artinya: Telah menceritakan kepada kami Abu Bakar bin Abu Syaibah telah menceritakan kepada kami Waki" dari Sufyan. (dalam riwayat lain disebutkan) Dan telah menceritakan kepada kami Muhammad bin alMutsanna telah menceritakan kepada kami Muhammad bin Ja"far telah menceritakan kepada kami Syu"bah keduanya dari Qais bin Muslim dari Thariq bin Syihab dan ini adalah hadits Abu Bakar, "Orang pertama yang berkhutbah pada Hari Raya sebelum sholat Hari Raya didirikan ialah Marwan. Lalu seorang lelaki berdiri dan berkata kepadanya, "Sholat Hari Raya hendaklah dilakukan sebelum membaca khutbah." Marwan menjawab, "Sungguh, apa yang ada dalam khutbah sudah banyak ditinggalkan." Kemudian Abu Said berkata, "Sungguh, orang ini telah memutuskan (melakukan) sebagaimana yang pernah aku dengar dari Rasululloh shallallohu „alaihi wasallam, bersabda: “Barangsiapa di antara kamu melihat kemungkaran hendaklah ia mencegah kemungkaran itu dengan tangannya. jika tidak mampu, hendaklah mencegahnya dengan lisan, jika tidak mampu juga, hendaklah ia mencegahnya dengan hatinya. Itulah selemah-lemah iman (Abu Isa Muhammad, tt). Hadits tersebut termasuk dalam fungsi dari bimbingan dan konseling Islam, yaitu tentang fungsi pencegahan. Dalam bimbingan dan konseling Islam, fungsi pencegahan sangatlah penting, karena fungsi ini akan menjadikan peserta didik mempunyai batasan dan juga mempunyai daya tanggap terhadap suatu perkara. Daya tanggap ini adalah kemampuan mengikatkan dalam tingakatan yang telah ditentukan. 


\section{Konseling Rational Emotif Behaviour Theraphy (Rebt)-Islami ...}

Suatu conoh apabila peserta didik, melihat tindakan pencurian di dalam kelas, peserta didik yang menjadi saksi langsung bisa menegurnya, dan apabila terjadi ancaman akan dilaporkan kepada guru di sekoloah.

Tujuan bimbingan dan konseling yang terkait dengan aspek akademik (belajar) adalah: (1) Memiliki kesadaran tentang potensi diri dalam aspek belajar, dan memahami berbagai hambatan yang mungkin muncul dalam proses belajar yang dialaminya. (2) Memiliki sikap dan kebiasaan belajar yang positif, seperti kebiasaan membaca buku, disiplin dalam belajar, mempunyai perhatian terhadap semua pelajaran, dan aktif mengikuti semua kegiatan belajar yang diprogramkan. (3) Memiliki motif yang tinggi untuk belajar sepanjang hayat (Hasyim \& Mulyono, 2010: 69).

Di samping tujuan sebagaimana tersebut di atas, bimbingan dan konseling dalam Islam juga memiliki tujuan yang secara rinci dapat disebutkan sebagai berikut: (1) Untuk menghasilkan suatu perubahan, perbaikan, kesehatan, dan kebersihan jiwa dan mental. Jiwa menjadi tenang, jinak, dan damai, (muthmainnah), bersikap lapang dada (radhiyah), dan mendapatkan pencerahan taufik dan hidayah Tuhannya (mardhiyah). (2) Untuk menghasilkan suatu perubahan, perbaikan, dan kesopanan, tingkah laku yang dapat memberikan manfaat, baik pada diri sendiri, lingkungan keluarga, lingkungan kerja, maupun lingkungan sosial dan alam sekitarnya. (3) Untuk menghasilkan kecerdasan rasa (emosi) pada individu sehingga muncul dan berkembang rasa toleransi, kesetiakawanan, tolongmenolong, dan rasa kasih sayang. (4) Untuk menghasilkan kecerdasan spiritual pada diri individu sehingga muncul dan berkembang rasa keinginan untuk berbuat taat kepada Tuhannya, ketulusan mematuhi segala perintah-Nya, serta ketabahan menerima ujian-Nya. (5) Untuk menghasilkan potensi Ilahiah, sehingga dengan potensi itu individu dapat melakukan tugasnya sebagai khalifah dengan baik dan benar, ia dapat dengan baik menanggulangi berbagai persoalan hidup, dan dapat memberikan kemanfaatan dan keselamatan bagi lingkungannya pada berbagai aspek kehidupan (Munir, 2013: 43).

Tujuan yang ingin dicapai melalui bimbingan dan konseling Islami adalah agar fitrah yang dikaruniakan Allah kepada individu 
bisa berkembang dan berfungsi dengan baik, sehingga menjadi pribadi yang kaffah, dan secara bertahap mampu mengaktualisasikan apa yang diimaninya itu dalam kehidupan sehari-hari, yang tampil dalam bentuk kepatuhan terhadap hukum-hukum Allah dalam beribadah dengan mematuhi segala perintah-Nya dan menjauhi segala larangan-Nya (Sutoyo, 2003: 21).

Fungsi utama bimbingan dan konseling dalam Islam yang hubungannya dengan kejiwaan tidak dapat terpisahkan dengan masalah-masalah spiritual (keyakinan). Islam memberikan bimbingan kepada individu agar dapat kembali pada bimbingan alQur"an dan as-Sunnah. Sedangkan fokus bimbingan dan konseling Islam selain memberikan perbaikan dan penyembuhan pada tahap mental, spiritual atau kejiwaan, dan emosional, seperti ungkapan dalam firman Allah: wayuzakkihim (dan mensucikan mereka), kemudian melanjutkan kualitas dari materi bimbingan dan konseling kepada pendidikan dan pengembangan dengan menanamkan nilainilai dan wahyu sebagai pedoman hidup dan kehidupan hidup, maka individu akan memperoleh wacana-wacana ilahiah tentang bagaimana mengatasi masalah, kecemasan dan kegelisahan, melakukan hubungan komunikasi yang baik dan indah, baik secara vertical maupun horizontal. Dan sekaligus individu akan mempunyai kemampuan al-Hikmah, yaitu metode atau cara untuk menghayati rahasia di balik berbagai peristiwa dalam kehidupan secara nurani, empirik, dan transendental. Dengan kemampuan dan pemahaman yang matang terhadap al-Qur"an dan al-Hikmah, maka secara otomatis individu akan terhindar dan tercegah dari hal-hal yang dapat merusak dan menghancurkan eksistensi dan esensi dirinya, baik kehidupan di dunia maupun kehidupan di akhirat (Munir, 2013: 45).

\section{Rational Emotive Behavior Theraphy (REBT) Islami}

Setelah umat Islam mengalami kemunduran sekitar abad 13-20 M, pihak Barat memanfaatkan kesempatan tersebut untuk mengembangkan ilmu pengetahuan yang telah dipelajarinya dari Islam, sehingga ia mencapai masa renaissance. Ilmu pengetahuan umum (sains) berkembang pesat di Barat, sedangkan ilmu pengetahuan Islam mengalami kemunduran, yang pada akhirnya muncullah dikotomi antara dua bidang ilmu tersebut.Tidak hanya 


\section{Konseling Rational Emotif Behaviour Theraphy (Rebt)-Islami ...}

sampai di sini, tetapi muncul pula sekularisasi ilmu pengetahuan di Barat yang mendapat tantangan dari kaum Gereja. Galileo (L.1564 M) yang dipandang sebagai pahlawan sekularisasi ilmu pengetahuan mendapat hukuman mati pada tahun $1633 \mathrm{M}$, karena mengeluarkan pendapat yang bertentangan dengan pandangan Gereja. Galileo memperkokoh pandangan Copernicus bahwa matahari adalah pusat jagat raya berdasarkan fakta empiris melalui observasi dan eksperimen. Sedangkan Gereja memandang bahwa bumi adalah pusat jagat raya (Geosentrisme) yang didasarkan pada informasi Bibel.

Peristiwa sejarah tersebut, menjadi pemicu lahirnya ilmu pengetahuan memisahkan diri dari doktrin agama. Kredibilitas Gereja sebagai sumber informasi ilmiah merosot, sehingga semakin mempersubur tumbuhnya pendekatan sainstifik dalam ilmu pengetahaun menuju ilmu pengetahuan sekuler. Sekularisasi ilmu pengetahuan secara ontologis membuang segala yang bersifat religius dan mistis, karena dianggap tidak relevan dengan ilmu. Alam dan realitas sosial didemitologisasikan dan disterilkan dari sesuatu yang bersifat ruh dan spiritualitas, yakni didesakralisasikan (di alam ini tidak ada yang sakral). Sekularisasi ilmu pengetahuan dari segi metodologi menggunakan epistemologi rasionalisme dan empirisme. Rasionalisme berpendapat bahwa rasio adalah alat pengetahuan yang obyektif karena dapat melihat realitas dengan konstan.

Sedangkan empirisme memandang bahwa sumber pengetahuan yang absah adalah empiris (pengalaman). Sekularisasi ilmu pengetahuan pada aspek aksiologi bahwa ilmu itu bebas nilai atau netral, nilai-nilai ilmu hanya diberikan oleh manusia pemakainya. Memasukkan nilai ke dalam ilmu, menurut kaum sekular menyebabkan ilmu itu "memihak", dan dengan demikian menghilangkan obyektivitasnya (Mufid, 2013).

Sementara Amin Abdullah memandang integrasi keilmuan mengalami kesulitan, yaitu kesulitan memadukan studi Islam dan umum yang kadang tidak saling akur karena keduanya ingin saling mengalahkan.Oleh karena itu, diperlukan usaha interkoneksitas yang lebih arif dan bijaksana. Interkoneksitas yang dimaksud oleh Amin Abdullah adalah usaha memahami kompleksitas fenomena kehidupan yang dihadapi dan dijalani manusia, sehingga setiap 
bangunan keilmuan apapun, baik keilmuan agama, keilmuan sosial, humaniora, maupun kealaman tidak dapat berdiri sendiri, maka dibutuhkan kerjasama, saling tegur sapa, saling membutuhkan, saling koreksi dan saling keterhubungan antara disiplin keilmuan. Pendekatan integratif-interkonektif merupakan pendekatan yang tidak saling melumatkan dan peleburan antara keilmuan umum dan agama (Abdullah, 2006)

Kuntowijoyo mengatakan bahwa al-Qur'an sesungguhnya menyediakan kemungkinan yang sangat besar untuk dijadikan sebagai cara berpikir. Cara berpikir inilah yang dinamakan paradigma al-Qur'an, paradigma Islam. Pengembangan eksperimeneksperimen ilmu pengetahuan yang berdasarkan pada paradigma alQur'an jelas akan memperkaya khasanah ilmu pengetahuan. Kegiatan itu mungkin menjadi pendorong munculnya ilmu-ilmu pengetahuan alternatif. Jelas bahwa premis-premis normatif al-Qur'an dapat dirumuskan menjadi teori-teori empiris dan rasional. Struktur transendental al-Qur'an adalah sebuah ide normatif dan filosofis yang dapat dirumuskan menjadi paradigm teoritis. Ia akan memberikan kerangka bagi pertumbuhan ilmu pengetahuan empiris dan rasional yang orisinal, dalam arti sesuai dengan kebutuhan pragmatis umat manusia sebagai khalifah di bumi. Itulah sebabnya pengembangan teoriteori ilmu pengetahuan Islam dimaksudkan untuk kemaslahatan umat Islam (Kuntowijoyo, 2004).

Begitu juga didalamkajian konseling, Abraham Maslow membagi empat mazhab besar disiplin Psikologi konseling, yaitu Psikoanalisa, Behaviorisme, Humanisme, dan Psikologi Transpersonal. Pembagian empat mazhab itu juga masih memiliki kelemahan, yaitu tidak memasukkan peran agama secara signifikan ke dalam disiplin konseling. Apalagi jika memperhatikan pendapat ilmuwan positivistik yang cenderung memisahkan agama dan ilmu pengetahuan. Padahal, kepribadian individu yang terbentuk dari unsur bio-psiko-spiritual sangat dipengaruhi oleh agama. Jadi tak mengherankan jika ahli Konseling Islam mengatakan bahwa Konseling Islam akan bergerak menjadi mazhab kelima dari disiplin psikologi dengan cara mengembalikan paradigma ilmuwan kepada orientasi dunia dan akhirat. 


\section{Konseling Rational Emotif Behaviour Theraphy (Rebt)-Islami ...}

Oleh karena itu, perlu ditekankan kajian keagamaan, baik hal itu berasal dari perspektif Indigenous Counseling yang cross cultural dan mengungkap variabel budaya lokal maupun Konseling Agama itu sendiri terhadap pembentukan karakter individu. Hal itu dipandang penting agar bisa mencapai tujuan kelima dari disiplin ilmu konseling, yaitu konseling mampu melakukan pengendalian (controlling) atau mengatur perilaku sesuai dengan yang diharapkan berdasarkan karakteristik individu yang dipengaruhi oleh faktor budaya dan agama. Orientasi perwujudannya adalah pada tugas konseling yang kelima tersebut, yaitu berupa tindakan pertolongan konseling atau treatment sesuai dengan latar belakang budaya dan agama seseorang (Hidayat, 2014).

Upaya dalam integrasi keilmuan dalam bidang konseling dapat dilakukan dengan integrasi pendekatan konseling dengan kajian Islam. Misalnya dengan mengintegrasikan pendekatan Rasional Emotif Behavior Therapy (REBT) dengan Islam. Hal ini berdasarkan pada intervensi berasal teori REBT jarang bertentangan dengan tradisi agama klien apalagi dalam konteks masyarakat Indonesia yang mayoritas beragama Islam. REBT juga biasanya mengakomodasi keyakinan agama klien bahkan ketika klien dan terapis memiliki orientasi keagamaan yang sangat berbeda. Apalagi karena intervensi REBT fokus begitu spesifik pada keyakinan, begitu juga agama (Islam) yang menjadikan keyakinan (keimanan) sebagai pondasi dalam beragama. Oleh karena itu REBT sangat cocok untuk mengintegrasikan keyakinan agama klien dalam intervensinya.

Dalam pendekatan konseling REBT mengintegrasikan materi keagamaan dengan Intervensi Rasional Emotif yang dapat membuat hidup klien sangat pribadi, kuat, dan mendalam khususnya bagi klien yang religious (beragama). Sebagai seorang konselor REBT tidak diperkenankan mengakomodasi keyakinan agama konselor kepada klien selama terapi, berikan kebebasan kepada klien untuk mengintegrasikan keyakinan agamanya. REBT pada dasarnya adalah psikoterapi konstruktivis, sangat akomodatif dan integratif dari nilai dan keyakinan klien, termasuk keyakinan agama. REBT menekankan pada pencarian keyakinan yang inti, memungkinkan untuk fokus dalam kesederhanaan dan keanggunan yang netral dengan 
menghormati sebagian besar hal khusus dalam situasi klien, termasuk hal-hal khusus dari keyakinan agama klien.

Meskipun REBT dapat dan biasanya mendekati sebagian besar masalah netral perspektif, konstruktivis, namun prinsipprinsip dasarnya cukup bersimpati dengan sebagian besar keyakinan agama dan "mungkin sebenarnya lebih dekat posisi doktrin keagamaan daripada kebanyakan pendekatan psikoterapi lain (DiGiuseppe, Robin, \& Dryden, 1990). Sejumlah terapis telah mencatat kesamaan mendalam antara REBT dan teologi keagamaan (Beaman, 1978; Beit-Hallahmi, 1980; Carter, 1986; W.B.Johnson, 1992; Jones, 1989; Lawrence, 1987; Lawrence \& Huber, 1982; Nielsen, 1994; Warnock, 1989; Young, 1984). Mencoba untuk membangun kesesuaian ini, REBT telah berkembang dan mengartikulasikan versi REBT yang berorientasi pada agama atau keyakinan tertentu (Backus, 1985; Hauck, 1972; W.B.Johnson, 1993; Nielsen, W.B.Johnson, \& Ridley, 2000; Powell, 1976; Robb, 1988; Stoop, 1982; Thurman, 1989).

Selain beberapa pendapat tersebut, terdapat lima realisasi terkait potensi REBT sebagai pendekatan yang diintegrasikan dengan pendekatan agama (Islam), yaitu: Pertama, karena kebanyakan orang adalah beragama, harapannya dengan konseling klien akan menjadi lebih religius. Ini berarti bahwa sebagian besar orang adalah berpartisipasi aktif atau taat secara informal ke tradisi agama, percaya pada tuhan atau agama, mistik, supernatural, atau prinsip spiritual atau kenyataan. Jadi, Mayoritas akan klien cenderung mempertahankan semacam keyakinan agama atau komitmen. Keyakinan agama klien terlihat menonjol dalam pandangan tentang kesulitan dan harapan mereka untuk solusi untuk masalah klien. Kedua, keyakinan agama klien dapat memberikan struktur penting kepada skema pengorganisasian kepribadian klien. Psikoterapi yang mengakomodasi atau mengintegrasikan keyakinan agama klien dalam intervensi lebih berpotensi menjadi sejalan dengan skema mengatur klien, dan karena itu cenderung lebih memfasilitasi proses terapi. Ketiga, REBT sejalan dengan sebagian besar tradisi keagamaan, dan menjadi pendekatan yang unik di antara kebanyakan model psikoterapi kontemporer, karena REBT berfokus pada keyakinan dan perubahan keyakinan. Agama yang terorganisir 
biasanya menanamkan kepercayaan khusus, memperkuat keyakinan ini, atau berusaha menanamkan keyakinan yang benar. Teori rasional emotif berbicara tentang pentingnya memahami efek dari keyakinan, tujuan REBT yang mendasar untuk mengubah keyakinan irasional, dan banyak teknik dalam rasional emotif yang mengubah keyakinan cenderung tampak lugas dan mungkin bahkan akrab bagi klien yang beragama. Keempat, banyak variasi dalam ajaran agama, seperti landasan dasar ajaran agama, doktrin, cerita, dan tradisi dalam agama besar sangat mendukung elemen fundamental dalam teori REBT. Ajaran fundamental dari tradisi agama tidak bertentangan secara substansial dengan teori atau tujuan rasional emotif yaitu mengurangi kekecewaan yang merugikan diri sendiri. Kelima, karena asumsi inti REBT dan tujuannya cenderung mendasari setidaknya agak mirip dengan prinsip-prinsip inti di sebagian besar sistem keagamaan, elemen fundamental dari tradisi agama klien dapat digunakan selama intervensi REBT yang berorientasi pada keyakinan. Ini menjadi semacam integrasi pendekatan (REBT dan agama/ Islam). Mengintegrasikan materi keagamaan dari tradisi religius klien dengan intervensi rasional emotif dapat meningkatkan efektivitas intervensi dengan membuatnya lebih jelas, lebih kuat, lebih luas, dan lebih dalam (Nielsen, Johnson, \& Ellis, 2001).

Oleh karena itu REBT Islami adalah sebuah pendekatan konseling mengakomodasi keyakinan agama klien bahkan ketika klien dan terapis memiliki orientasi keagamaan yang sangat berbeda yang berfokus pada keyakinan (agama Islam) yang mana keyakinan agama klien dapat memberikan struktur penting kepada skema pengorganisasian kepribadian klien. Maka REBT Islami sangat cocok untuk mengintegrasikan keyakinan agama klien dalam intervensi konseling. Dalam pendekatan konseling REBT mengintegrasikan materi keagamaan dengan Intervensi konseling yang dapat membuat hidup klien sangat pribadi, kuat, dan mendalam khususnya bagi klien yang religious (beragama). Selanjutnya Sebagai seorang konselor REBT tidak diperkenankan mengakomodasi keyakinan agama konselor kepada klien selama terapi, berikan kebebasan kepada klien untuk mengintegrasikan keyakinan agamanya. 


\section{Simpulan}

Upaya dalam integrasi keilmuan dalam bidang konseling dapat dilakukan dengan integrasi pendekatan konseling dengan kajian Islam. Misalnya dengan mengintegrasikan pendekatan Rasional Emotif Behavior Therapy (REBT) dengan Islam. Hal ini berdasarkan pada (1) intervensi berasal teori REBT jarang bertentangan dengan tradisi agama klien apalagi dalam konteks masyarakat Indonesia yang mayoritas beragama Islam. (2) Intervensi REBT begitu spesifik fokus pada keyakinan, begitu juga agama (Islam) yang menjadikan keyakinan (keimanan) sebagai pondasi dalam beragama. (3) Dalam pendekatan konseling REBT Islami mengintegrasikan materi keagamaan dengan Intervensi Rasional Emotif yang dapat membuat hidup klien sangat pribadi, kuat, dan mendalam khususnya bagi klien yang religious (beragama). (4) Sebagai seorang konselor REBT Islami tidak diperkenankan mengakomodasi keyakinan agama konselor kepada klien selama terapi, berikan kebebasan kepada klien untuk mengintegrasikan keyakinan agamanya. Oleh karena itu REBT sangat cocok untuk mengintegrasikan keyakinan agama klien dalam intervensinya. 


\section{Konseling Rational Emotif Behaviour Theraphy (Rebt)-Islami ...}

\section{DAFTAR PUSTAKA}

Abdullah, M. A. (1999). Visi Keindonesiaan Pembaharuan Pemikiran Islam Hermeneutik. Jurnal Epistema, 3(2). Retrieved from https://www.scribd.com/document/367487398/35-131-1-PBpdf

Abdullah, M. A. (2006). Islamic Studies di Perguruan Tinggi: Pendekatan Integratif-Interkonektif. Pustaka Pelajar.

Abu Isa Muhammad, B. I. Bs. (tt). Al-Jami' Ash-Shahih Sunan Tirmidzi (Vol. V). Beirut: Dar Al-Kutub Al-Ilmiyyah.

Ackerman, C. (2017). What is Rational Emotive Behavior Therapy? Jornal of Positive Psychology Program, 8. Retrieved from https://positivepsychologyprogram.com/rational-emotivebehavior-therapy-rebt/

Corey, G. (2012). Theory and Practice of Counseling and Psychotherapy (9th ed.). Cengage Learning.

Depag RI. (2010). Al-Qur'an dan Tafsirnya. Jakarta: Lentera Abadi.

DiGiuseppe, R., Robin, M. W., \& Dryden, W. (1990). On the compatibility of Rational-Emotive therapy and Judeo-Christian philosophy: A focus on clinical strategies. Journal of Cognitive Psychotherapy, 4, 355-368.

Dryden, W. (2012). The "ABCs" of REBT I: A Preliminary Study of Errors and Confusions in Counselling and Psychotherapy Textbooks. Journal of Rational-Emotive \& Cognitive-Behavior Therapy, 30(3), 133-172. https://doi.org/10.1007/s10942-0110137-1

Ellis, A. (1958). Rational psychotherapy and individual psychology. Journal of Individual Psychology.

Ellis, A., \& Dryden, W. (1997). The Practice of Rational-emotive Behavior Therapy. New York: Springer Publishing Company.

Faiz, F. (2007). Islamic Studies dalam Paradigma IntegrasiInterkoneksi. Yogyakarta: Suka Press.

Farid, I. S. (2007). Pokok-pokok Bahasan tentang Bimbingan Penyuluhan Agama sebagai Tenik Dakwah. Jakarta: Bulan Bintang.

Hasyim, F., \& Mulyono. (2010). Bimbingan dan Konseling Religius. Yogyakarta: AR-RUZZ MEDIA. 
Hidayat, B. (2014). Psikologi Islam. Riau: Psikologi UIN Sultan syarif kasim.

Kuntowijoyo. (2004). Islam sebagai ilmu: epistemologi, metodologi, dan etika. Teraju.

Mu'awanah, E., \& Hidayah, R. (2009). Bimbingan konseling Islami di sekolah dasar. Bumi Aksara.

Mufid, F. (2013). Integrasi Ilmu-Ilmu Islam. Jurnal Equilibrium, 1(1), 55-71.

Mulyasa, E. (2003). Kurikulum Berbasis Kompetensi (Konsep, Karakteristik, Implementasi, dan Inovasi). Bandung: Remaja Rosdakarya.

Munir, S. (2013). Bimbingan dan Konseling Islam. Jakarta: Amzah.

Nasr, S. H., Suharsono, \& MZ, D. (Trans.). (1996). Intelektual Islam: Teologi, Filsafat dan Gnosis. Yogyakarta: Pustaka Pelajar.

Natawidjaya, R. (2009). Konseling Kelompok Konsep Dasar dan Pendekatan. Bandung: Rizqi Press.

Nielsen, S. L., Johnson, W. B., \& Ellis, A. (2001). Counseling And Psychotherapy With Religious Persons: A Rational Emotive Behavior Therapy Approach. Choice Reviews Online, 39(04), 392480-39-2480. https://doi.org/10.5860/CHOICE.39-2480

Sukardi, D. K. (2008). Pengantar teori konseling. Ghalia Indonesia.

Surya, M. (1988). Dasar-Dasar Konseling Pendidikan, Teori Dan Konsep. Bandung: Kota Kembang.

Sutoyo, A. (2003). Bimbingan \& Konseling Islami (Teori dan Praktik) (1st ed.). Yogyakarta: Pustaka Pelajar.

Syamsu, Y., \& Juntika, N. (2005). Landasan Bimbingan Dan Konseling. Bandung: Remaja Rosdakarya.

Tim Penyusun. (1988). Kamus Besar Bahasa Indonesia. Jakarta: Balai Pustaka.

Vandestra, M., \& Muslim, I. (2017). Kitab Hadist Shahih Muslim Ultimate. Dragon Promedia.

Winkel, W. S. (2005). Bimbingan dan konseling di institusi pendidikan. Media Abadi. 